\title{
EFFECT OF ADDING DOWNSTREAM BERMS ON SEISMIC MITIGATION OF EMBANKMENTS
}

\author{
Safia Mohamed Khodary ${ }^{1,}$, Kamal Mohamed Hafez Ismail Ibrahim ${ }^{2}$ \\ ${ }^{1}$ Post Graduate Student, Aswan University, Egypt \\ 2 Assoc. Prof., Civil Engineering Dep., Suez Canal University, Egypt \\ Received 30 January 2014; accepted 25 February 2014
}

\begin{abstract}
This paper investigates the performance of embankments subjected to seismic loading. Finite element analysis using Plaxis dynamic software program was carried out to evaluate the crest settlement of a dense sand embankment on rock foundation before and after adding downstream berms. Undraind analysis is carried out using Mohr-Coulomb criteria. The numerical intensities are close to previous studies and the results show that the best embankment performance is when the berm is added in downstream at height equals to half of the embankment total height. The downstream berm slope has no significant effect on crest settlement for slopes less than $1.5 \mathrm{H}$ : $1 \mathrm{~V}$. It is also found that when adding two downstream berms, the best mitigation is obtained when the top berm is at two third the embankment and the bottom berm is added at one third the total embankment height.
\end{abstract}

Keywords: Seismic mitigation, Downstream Berms, Finite Element, Crest settlement

\section{Introduction}

The effect of seismic hazards due to earthquakes on embankments and dams can be grouped into four categories: instability of slopes, crest settlement, cracking in dam body and liquefaction in foundation. These may occur separately or together. The conventional design method of embankment for earthquake loading is based on equivalent static approach in which a horizontal seismic ratio is applied on rigid sliding masses in limit equilibrium method (Meysam Fadaee et al.[1]).

In order to prevent the disastrous events, several seismic retrofit methods are available in practice. The retrofit methods which can be utilized in different damage conditions are berm construction, excavation and replacing improper soils, increasing freeboard and subsoil improvement techniques which can be divided into four categories: densification techniques (such as, vibro techniques, dynamic compaction, blasting, and compacting grouting), reinforcement techniques (such as, stone columns and compaction piles), grouting / mixing techniques (such as, Permeation Grouting, intrusion grouting, jet grouting and compaction grouting), and drainage techniques (Steven [2]).

Vlad Perlea et al [3] studied an embankment dam, approximately 140 feet high and over one mile long located in a zone of moderate seismicity in Eastern Kansas, numerous seismic retrofit solutions were studied, including adding downstream berms.

Meysam Fadaee et al. [1] by using the finite element program "CA2" reported that, the best seismic embankment performance was obtained by adding a berm at $25 \mathrm{~m}$ height (at half the dam height) in which minimum crest settlement and minimum shear strain in dam body.

Figure 1 shows the typical maximum crest settlements for four different dam models;

model (a) initial dam model; model (b) added berm with increasing crest width; model (c) added berm with elevation equal to half of dam height; and model (d) added berm with

\footnotetext{
* Corresponding author.

Email address: safia.mohammed4@gmail.com
} 
elevation equal to one third of dam height. It is noticed that minimum crest settlement is obtained in case of model (c).

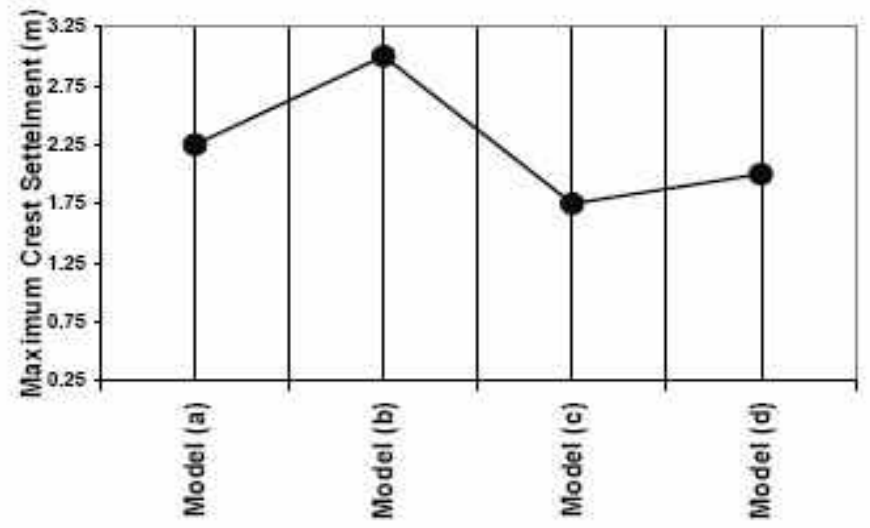

Fig. 1. Maximum crest settlements for four different dam models :( Meysam Fadaee et al. [1])

Antonio Fernandez [4] has produced a remediation to evaluate the liquefaction potential of earth embankment dams located within high risk seismic regions. This remediation concept began with the idea of constructing a large magnitude downstream berm. This soil structure will create a virtual dam that would prevent crest overtopping in the event of liquefaction of the dam. The presence of berm increases both the effective strength at downstream slope and forms a virtual dam that would serve as a containment structure for any liquefied material.

\section{Finite element modeling}

The analysis was carried out by the dynamic version finite element computer program (PLAXIS [5]). The program is developed in Holland for the two and three-dimensional analysis of geo-structures and geotechnical engineering problems. Soil and structures are often subjected not only to static loads, but if loads are powerful, as in earthquakes, they may cause severe damages. PLAXIS dynamic version considers the effect of vibration in the soil.

The studied model consists of embankment 30 meters in height, 10 meters in width and with side slopes 1:1. The foundation soil is 30 meters rock.

Figure 2 shows a cross section of embankment model and foundation soil. The analysis is modeled as plane strain and the soil mesh consists of 15-node triangular elements. Side and bottom standard fixities are used for restricted displacements. Side absorbent boundaries are introduced to prevent seismic wave reflection. Bottom prescribed displacement is applied to represent the seismic loading to simulate the applied earthquake data. 


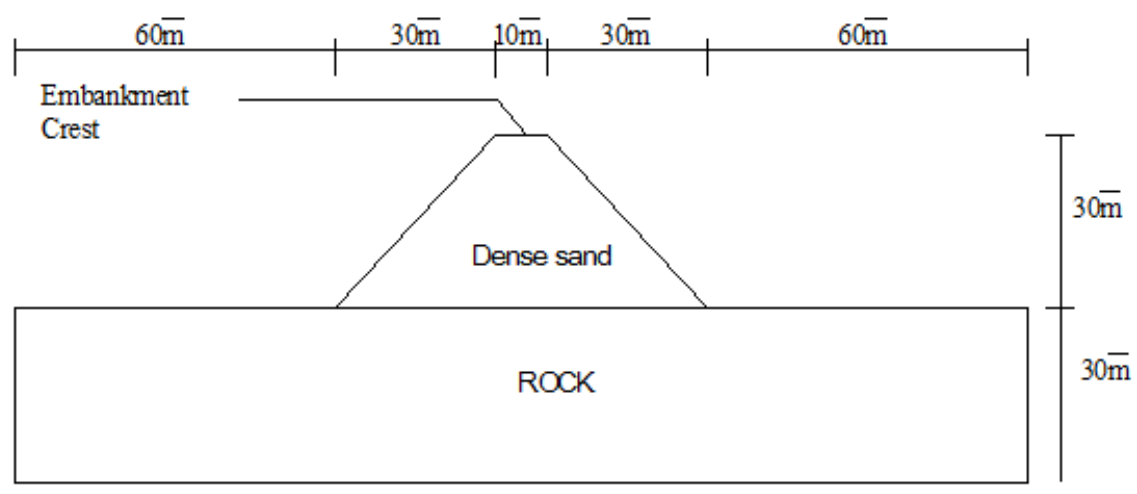

Fig. 2. Problem idealization (model a)

\section{Material properties}

Material properties of embankment soil and foundation rock are given in table 1.

\section{Table1 1.}

Soil properties

\begin{tabular}{|l|c|c|}
\hline Parameters & $\begin{array}{c}\text { Embankment body } \\
\text { and berm (dense sand) }\end{array}$ & $\begin{array}{c}\text { Foundation } \\
\text { (rock) }\end{array}$ \\
\hline Material model & MC & Elastic \\
\hline Behavior type & Undrained & Undrained \\
\hline Density $\left(\mathrm{KN} / \mathrm{m}^{3}\right)$ & 20 & 25 \\
\hline Friction angle $\left(\Phi^{\circ}\right)$ & 38 & 48 \\
\hline Cohesion $\left(\mathrm{kN} / \mathrm{m}^{2}\right)$ & 5 & 50 \\
\hline Poisson ratio, $\nu$ & 0.25 & 0.2 \\
\hline Elasticity model, $\mathrm{E}\left(\mathrm{kN} / \mathrm{m}^{2}\right)$ & 80000 & 400000 \\
\hline
\end{tabular}

Plaxis can calculate $V_{s}$ (shear wave velocity) and $V_{p}$ (compression wave velocity) for the dense sand and the rock using the relation:

$$
\begin{aligned}
& \mathrm{V}_{\mathrm{s}}=\sqrt{G / \rho}=\sqrt{E / 2 \rho(1+v)} \\
& \mathrm{V}_{\mathrm{p}}=\sqrt{(1-v) E /(1+v)(1-2 v) \rho}
\end{aligned}
$$

(Rollins et al [6] )

Where: $\mathrm{G}=$ Shear modulus of soil.

$$
\begin{array}{ccc}
- & \rho= & \text { Mass density }=\gamma / g \\
\text { E, } v & \text { Dynamic young's modulus, poisson's ratio of soil }
\end{array}
$$

The generation of water pressure can be skipped, since the pore water pressure is not considered in this model. The global coarseness is set to medium in the mesh menu; figure 3 illustrates the mesh generated in the program. The calculations involve two phases; Phase 1 is plastic analysis using Mohr Column criteria considering construction stage heights. Phase 2 is dynamic analysis in which the seismic Petrolli earthquake with peak ground acceleration (PGA) equals $4.135 \mathrm{~m} / \mathrm{sec} 2$ load is applied as prescribed displacements at the bottom boundary of model a (without downstream berm).

Figure 4 shows the acceleration time history of Petrolli earthquake. 

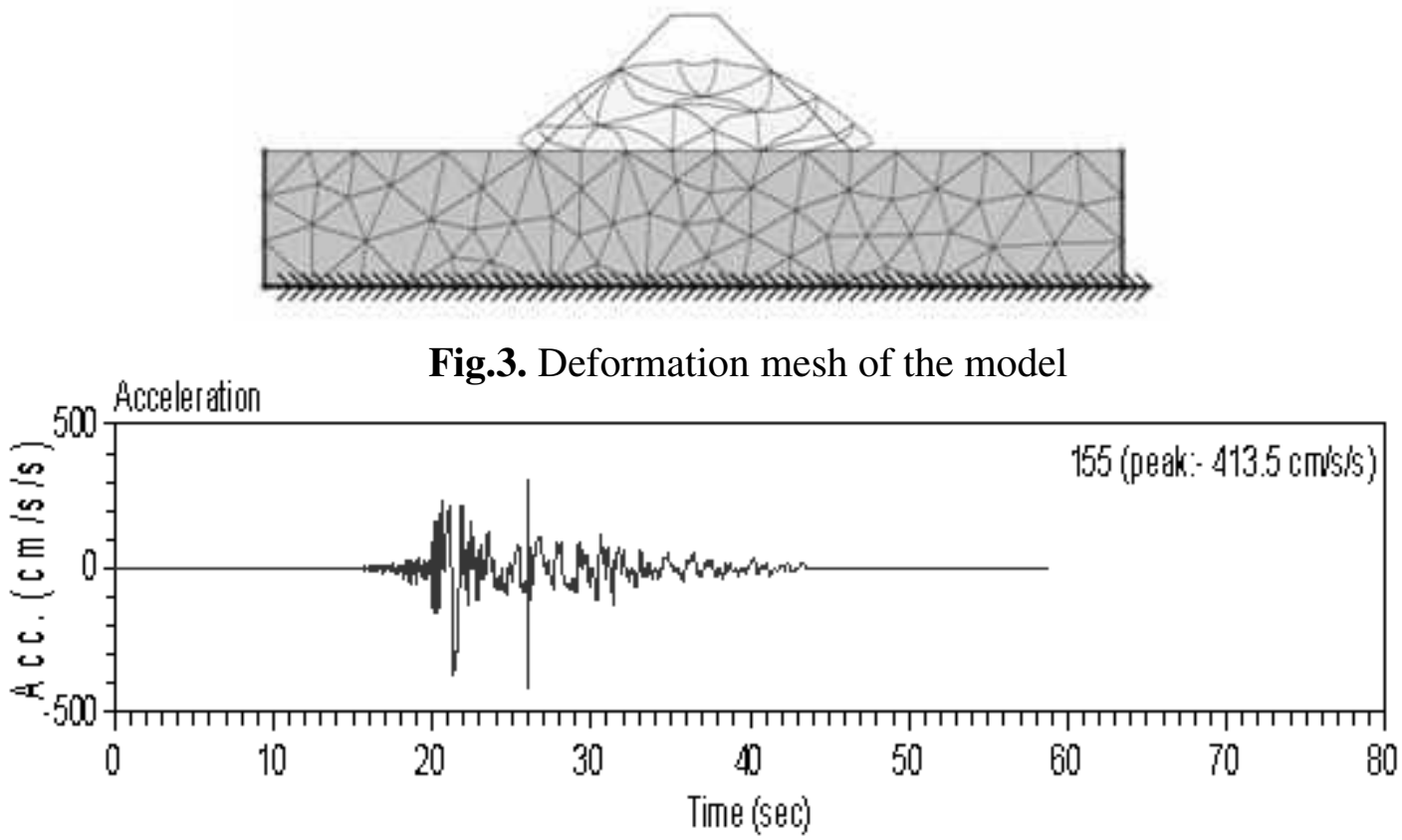

Fig. 4. Petrolli earthquake record applied on the model

\section{Seismic mitigation of embankment by adding downstream berms}

One of the methods used to enhance the seismic safety of embankments which suffer from deficient stability against earthquake is by adding downstream berms. Berms increase the effective overburden pressure; thus increase the resistance to liquefaction. They also increase the length of failure surface and provide a counterweight against the driving forces (Vlad et al [3]).

The plastic analysis using Mohr Column criteria considering construction stage resulted from analysis is $10 \mathrm{~cm}$ while the numerical dynamic crest settlement of embankment during the first 45 minutes under effect of Petrolli earthquake resulted from analysis is 2.63 $\mathrm{m}$ as shown in figure 5 .

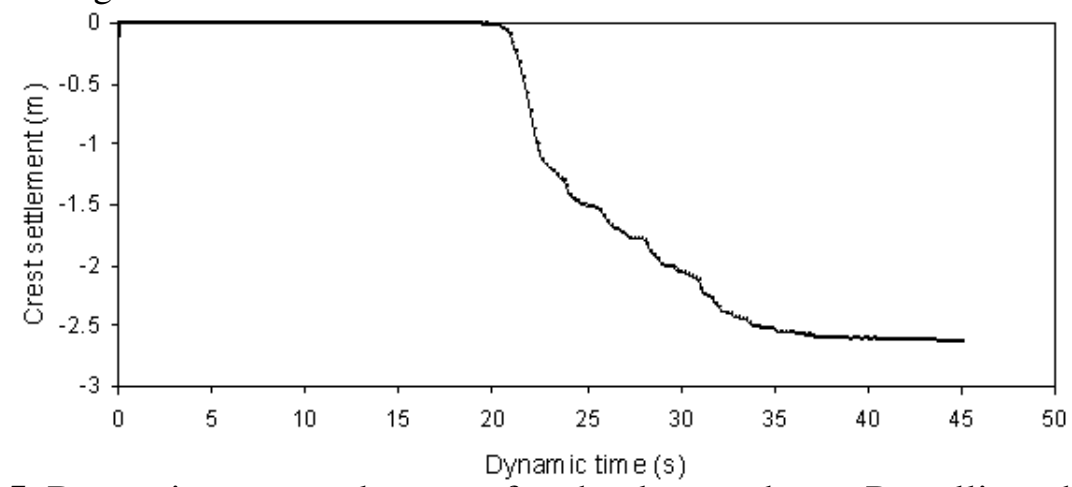

Fig. 5. Dynamic crest settlement of embankment due to Petrolli earthquake

The embankment volume equals $1200 \mathrm{~m} 3$ per unit length . The material properties of studied berm conditions are assumed identical to embankment body.To find the best level for the added berm with same construction cost, the berm volume is assumed constant in 
all models with different percentages of the volume of the original model $(10 \%, 15 \%$, $20 \%$, and $25 \%$ ).

There were three different options for the shape of berm added in downstream;

1 - Added berm increasing crest width (model b)

2- Added berm with elevation equal to half of dam height (model c)

3- Added berm with elevation equal to one third of dam height (model d).

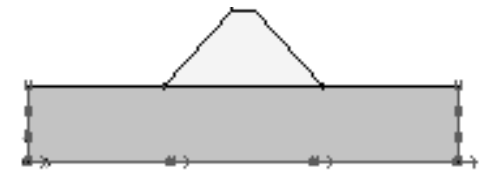

Model (a)

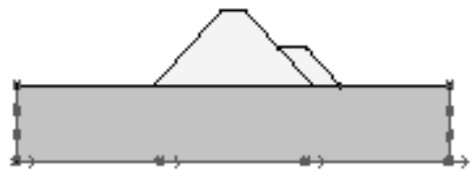

Model (c)

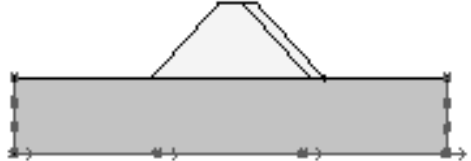

Model (b)

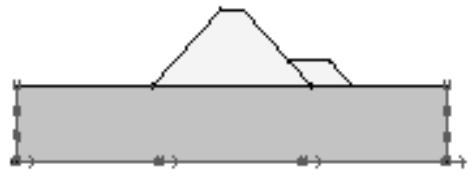

Model

Fig. 6. The different options for the shape of added berm

\section{Results and discussion}

\subsection{Effect of berm height on crest settlement}

It is noticed that best performance was obtained in case of model $\mathrm{c}$ where the berm is at $15 \mathrm{~m}$ height (half of embankment height) achieving minimum intensity of crest settlement as shown in the figure 7.

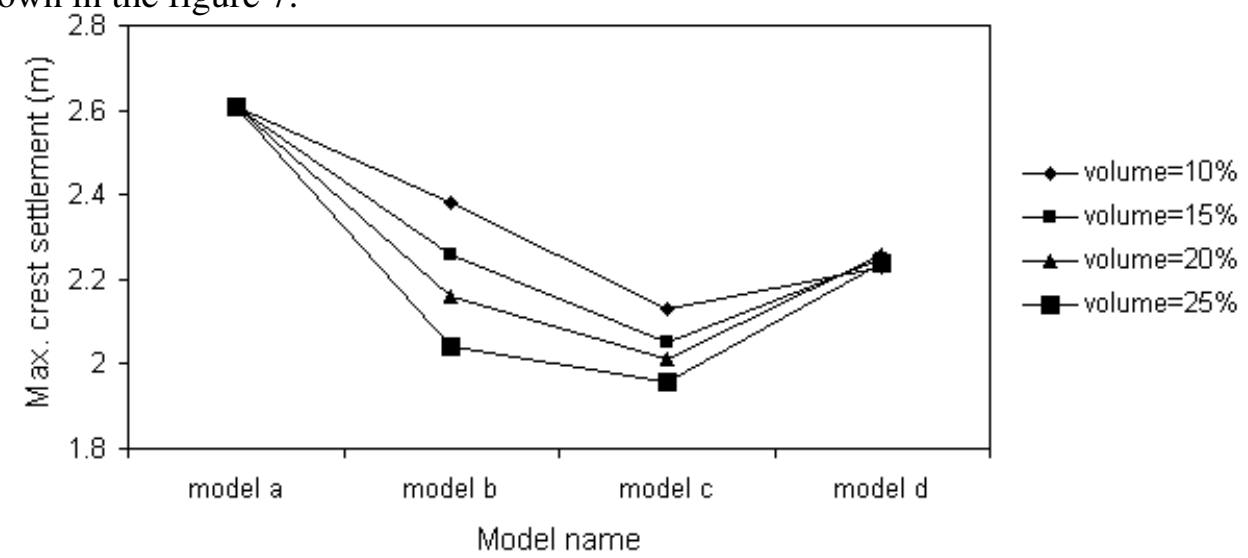

Fig. 7. Maximum crest settlement with different four models

\subsection{Effect of berm slope on crest settlement}

The berms volume is chosen constant in all trails and equals $25 \%$ of the total embankment volume and the berm height equals $15 \mathrm{~m}$. The downstream side slopes are 
1.5:1, 2:1, 2.5:1 and 3:1 H:V respectively. It is found that the crest settlement is about 1.96 $\mathrm{m}$ in most trials, figures 6-1 to 6-4.

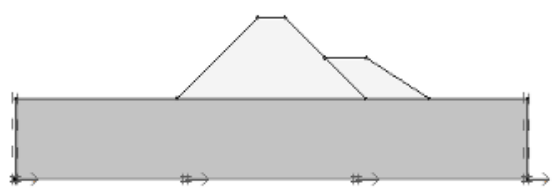

Fig. 6. 1. Berm slope $1.5 \mathrm{H}: 1 \mathrm{~V}$

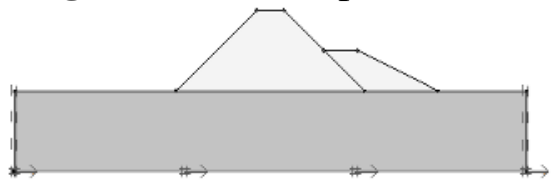

Fig. 6. 2. Berm slope $2 \mathrm{H}: 1 \mathrm{~V}$

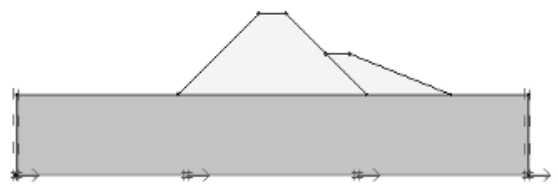

Fig. 6. 3. Berm slope $2.5 \mathrm{H}: 1 \mathrm{~V}$

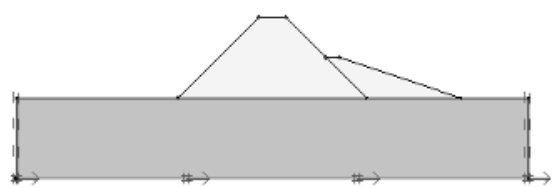

Fig. 6. 4. Berm slope $3 \mathrm{H}$ : $1 \mathrm{~V}$

The analyses demonstrated that the increase in crest settlement is reduced if the berm slope is less than 1.5:1. In all cases the maximum crest settlement ranges between 1.96 and $2.05 \mathrm{~m}$. Changing the berm slope has not significant effect on its maximum crest settlement. The results are presented in figure 7.

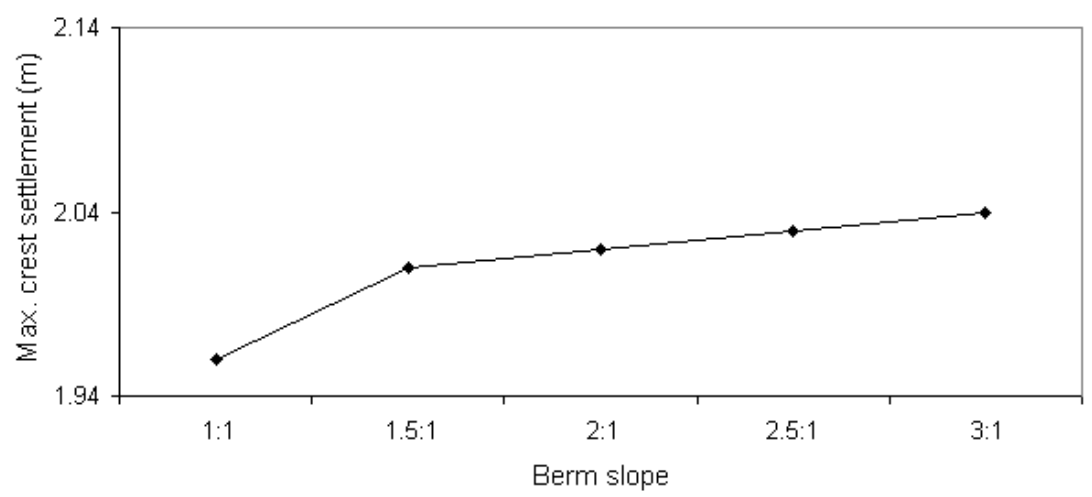

Fig. 7. Effect of berm slope on crest settlement

\subsection{Effect of adding two berms on crest settlement}

All berms volumes were assumed to be constant in all trails $25 \%$ of the main embankment volume. Figures 8 indicate different models for the shapes of added the 
berms to the main embankment. Figure 9 shows that model 3 is the best one in reducing the maximum crest settlement from $1.96 \mathrm{~m}$ (model 1) to $1.8 \mathrm{~m}$.

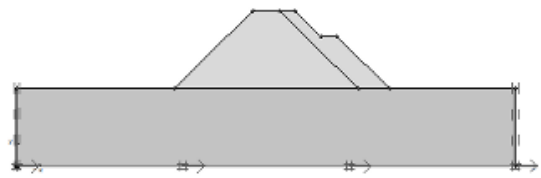

Mndel (1)

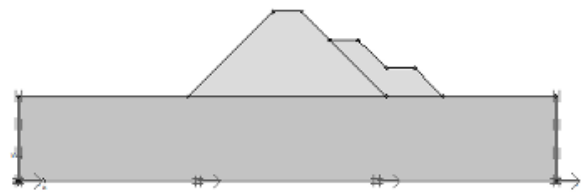

Model (3)

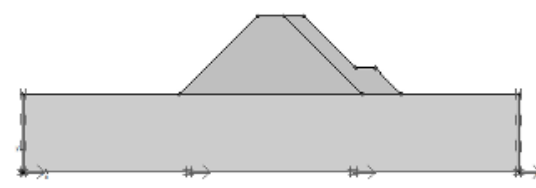

Model (2)

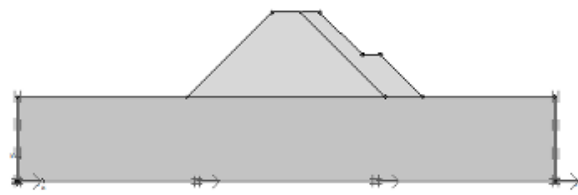

Model (4)

Fig. 8. Model (1) the top berm is at the crest and the bottom berm is at height $20 \mathrm{~m}$.

Model (2) the top berm is at the crest and the bottom berm is at height $10 \mathrm{~m}$. Model (3) the top berm is at height $20 \mathrm{~m}$ and the bottom berm is at height $10 \mathrm{~m}$. Model (4) the top berm is at the crest and the bottom berm is at height $15 \mathrm{~m}$

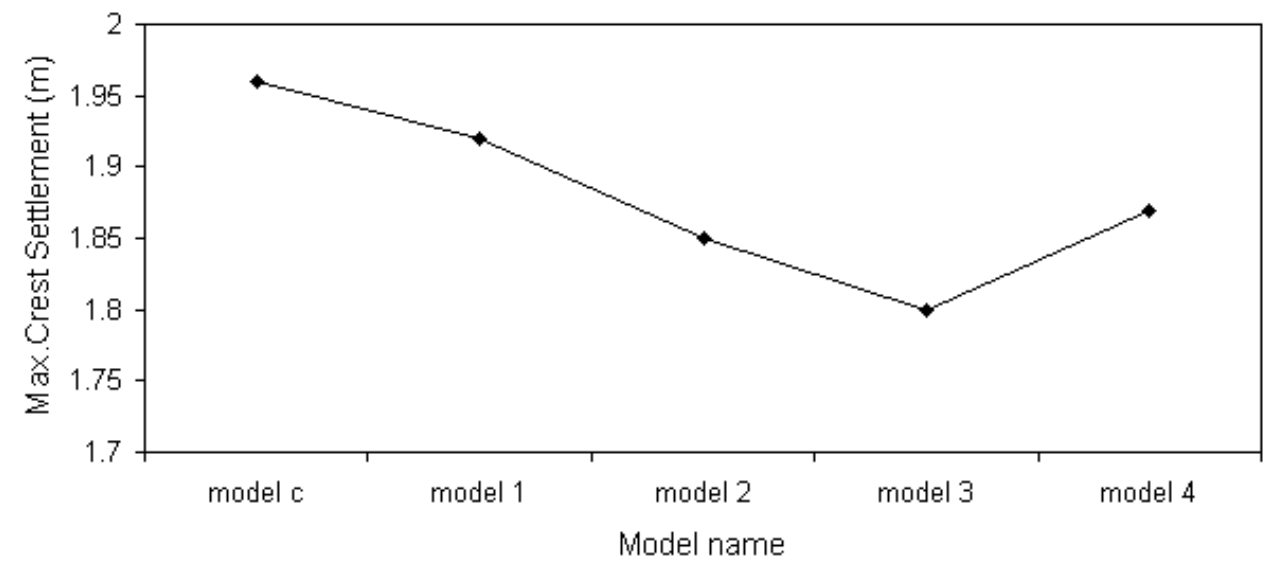

Fig. 9. Maximum crest settlement of different models

\section{Conclusions}

A series of numerical analysis have been carried out to evaluate the crest settlement of embankment under seismic loading using finite element numerical program "PLAXIS dynamic". In this paper, adding downstream berms was used to reduce the crest settlement.

Following conclusions can be drawn from this study:

1- Construction of downstream berm can reduce the crest expected settlement.

2-The best performance for the embankment when subjected to seismic loading is obtained when the downstream berm is constructed at half the embankment height (one berm only). 
3- Berm slope has minor effect on crest settlement.

And this agree with the findings of Meysam et al [1]

4 - In the case of adding two downstream berms, the best performance was obtained when the top berm and the bottom berm are at heights two third and one third the total embankment height respectively (Model 3 ) .

\section{References}

[1] Meysam Fadaee, Mahmoud Yazdani, and Ali Azad, 2008, "Seismic Retrofit of Embankment Dams Based on Dynamic Nonlinear Analyses", The 12th International Conference of International Association for Computer Methods and Advances in Geomechanics (IACMAG), 1-6 October, India, 4183-4191.

[2] Steven L. Kramer, (1996), "Geotechnical Earthquake Engineering", Prentice-Hall, Inc., Upper Saddle River, New Jersey.

[3] Vlad Perlea, David Mathews and William Empson, (2004), " Evaluation of alternatives for earthquake hazards mitigation of embankment dam in Kansas", 13th World Conference on Earthquake Engineering Vancouver, B.C., Canada, August 1-6, Paper No. 1895.

[4] Antonio Fernandez, "Liquefaction of Earth Embankment Dams, Tow Case Histories (1) Liquefaction of Embankment Soils, and (2) Liquefaction of Foundation Soils" ,Ph.D.

[5] Brinkgreve R. B. and Vermeer,(2002), Plaxis manual 2D - v. (8.1), general information, Delft university, Netherlands.

[6] Rollins K M, Evans M D, Diehl N B and Daily W D,(1998), " Shear modulus and damping relationships" . J. Geotech. Geoenv. Engg., ASCE 124 , Vol. 5, 396-405.

\section{تأثير اضافة المساطيح الخلفية على تقليل المخاطر الزلزالية للجسور}

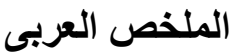

يوضح هذا البحث أداء الجسور المعرضة للأحمال الزلز الية حيث تم التحليل بطريقة العناصر المحددة لتقدير

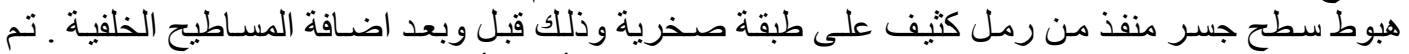

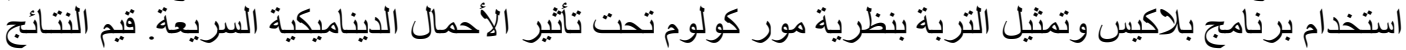

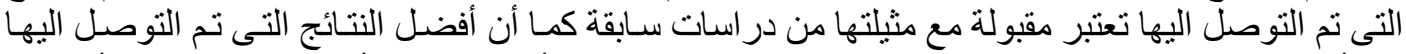

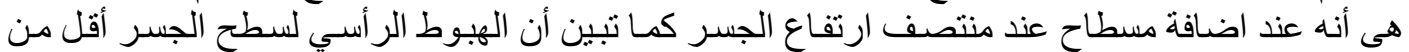

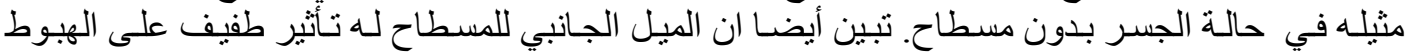

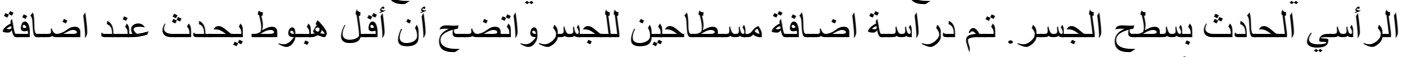
مسطاح علوي وآخر سفلي عند ثلثي ارتفاع الجسر وثلث ارتفاع الجسر. 